\title{
A Double TRPtych: Six Views of Transient Receptor Potential Channels in Disease and Health
}

\author{
Robert A. Cornell, ${ }^{1}$ Michelle Aarts, ${ }^{2}$ Diana Bautista, ${ }^{3}$ Jaime García-Añoveros, ${ }^{4}$ Kirill Kiselyov, ${ }^{5}$ and Emily R. Liman ${ }^{6}$ \\ ${ }^{1}$ Department of Anatomy and Cell Biology, Carver College of Medicine, University of Iowa, Iowa City, Iowa 52242, ${ }^{2}$ Department of Biological Sciences, \\ University of Toronto, Scarborough, Toronto, Ontario, Canada M1C 1A4, ${ }^{3}$ Department of Molecular and Cell Biology, University of California, Berkeley, \\ Berkeley, California 94720, ${ }^{4}$ Departments of Anesthesiology, Physiology, and Neurology, Northwestern University, Chicago, Illinois 60611, ${ }^{5}$ Department of \\ Biological Sciences, University of Pittsburgh, Pittsburgh, Pennsylvania 15260, and ${ }^{6}$ Department of Biological Sciences/Neurobiology, University of Southern \\ California, Los Angeles, California 90001
}

At the 2008 Annual Meeting of the Society for Neuroscience, a Mini-Symposium entitled "Contributions to TRP Channels to Neurological Disease" included talks from six heads of newly established laboratories, each with a unique research focus, model system, and set of experimental tools. Some of the questions addressed in these talks include the following. What is the role of transient receptor potential (TRP) channels in pain perception? How do normally functioning TRP channels contribute to cell death pathways? What are the characteristics of TRPpathies, disease states that result from overactive or underactive TRP channels? How are TRP channels regulated by signal transduction cascades? This review summarizes recent results from those laboratories and provides six perspectives on the subject of TRP channels and disease.

Key words: cation channel; melanocyte; mucolipidosis type IV; nociception; pain; TRP; amyotrophic lateral sclerosis/parkinsonism dementia complex; taste; cell death; lysosomal storage disease; TRPA1; TRPM5; TRPM7; TRPM8; TRPML1; TRPML3

Transient receptor potential (TRP) channels comprise a large family of cation channels. The founding member of this family, Drosophila TRP, is essential for phototransduction and is opened in response to rhodopsin-coupled phospholipase C (PLC) signaling (for review, see Montell, 2005). To date, >100 TRP channel genes have been identified, in organisms ranging from yeast to mice, and they are divided into seven distinct subclasses based on their primary sequences. Equally diverse are the physiological functions of TRP channels, in processes including taste, thermosensation, hearing, and calcium and magnesium homeostasis (for review, see Flockerzi, 2007). The breadth of TRP channel functions, and the intensity of investigations into these functions, is reflected in the large number of recent reviews covering aspects of TRP biology, such as TRP channel pharmacology (Okuhara et al., 2007), TRP channel structural biology (Gaudet, 2008), connections of TRP channels and cell death (McNulty and Fonfria, 2005), trafficking of TRP channels (Ambudkar, 2007), and TRP channels in disease (Nilius, 2007). The objective of the current review is to summarize results presented, in six presentations, at a Mini-Symposium at the 2008 Annual Meeting of the Society for Neuroscience entitled "Contributions of TRP Channels to Neuro-

Received Aug. 18, 2008; revised Sept. 15, 2008; accepted Sept. 17, 2008.

This work was supported by National Institutes of Health Grants DC004564 (Liman laboratory), GM067841 (Cornell laboratory), and NS044363 (García-Añoveros laboratory).

All authors contributed equally to the writing of this review.

Correspondence should be addressed to Robert A. Cornell, 1-532 Bowen Science Building, Department of Anatomy and Cell Biology, Carver College of Medicine, University of lowa, lowa City, IA 52242. E-mail: robert-cornell@uiowa.edu.

DOI:10.1523/JNEUROSCI.3929-08.2008

Copyright $\odot 2008$ Society for Neuroscience $\quad$ 0270-6474/08/2811778-07\$15.00/0 logical Disease" (Table 1). This field is moving rapidly and seems likely to be the focus of energetic investigation for years to come.

\section{TRP channels contribute to pain sensation}

Pain is a clinically important element of countless diseases. Several members of the TRP channel family have been proposed to play key roles in pain and inflammation (Jordt et al., 2003; Wang and Woolf, 2005; Dhaka et al., 2006). In mammals, the initial detection of noxious chemical, mechanical, or thermal stimuli, a process referred to as nociception, is mediated by specialized somatosensory neurons called nociceptors. Natural plant-derived irritants have served as powerful pharmacological tools for elucidating the molecular mechanisms underlying nociception, as illustrated by the use of capsaicin to identify the heat-activated ion channel TRPV1 (Caterina et al., 1997). The characterization of TRPV1-deficient animals has demonstrated an essential role for TRPV1 in both heat transduction and inflammation-evoked thermal hypersensitivity (Caterina et al., 2000). The menthol receptor TRPM8 and the wasabi receptor TRPA1 have also been proposed to play key roles in nociceptor function (McKemy et al., 2002; Story et al., 2003; Jordt et al., 2004; Nagata et al., 2005). To probe the physiological roles of these channels, Diana Bautista (University of California, Berkeley, Berkeley, CA) and her colleagues in David Julius' laboratory at the University of California, San Francisco (San Francisco, CA) have generated TRPM8- and TRPA1-deficient mice and have tested them in a variety of in vitro and in vivo assays.

TRPA1 is activated by a number of environmental chemicals that induce inflammatory pain. These include allyl isothiocyanate and allicin, the pungent compounds found in mustard and 
Table 1. TRP channels studied in our laboratories

\begin{tabular}{|c|c|c|}
\hline TRP family member & Connection to disease or pathology & Reviewed by \\
\hline \multirow[t]{5}{*}{ TRPM7 } & Wild-type form promotes excitotoxic cell death (Aarts et al., 2003) & Aarts and Tymianski, 2005 \\
\hline & Hypomorphic variant associated with Guamanian amyotrophic lateral sclerosis/parkinsonism-demen- & \\
\hline & tia complex (Hermosura et al., 2005) & Hermosura and Garruto, 2007 \\
\hline & Hypomorphic alleles cause melanocyte cell death and paralysis in zebrafish mutants (Kelsh et al., & \\
\hline & 1996; Arduini and Henion, 2004; Cornell et al., 2004; Elizondo et al., 2005). & luga and Lerner, 2007 \\
\hline TRPML1 & Hypomorphic form causes MLIV (Bargal et al., 2000; Bassi et al., 2000; Sun et al., 2000) & Slaugenhaupt, 2002; Bach, 2005 \\
\hline TRPA1 & Wild-type form mediates inflammatory pain in mice (Bautista et al., 2006) & Story, 2006 \\
\hline TRPM8 & Wild-type form mediates cold-induced pain in mice (Bautista et al., 2007) & Story, 2006 \\
\hline TRPML3 & $\begin{array}{l}\text { Mutant forms cause death of hair cells and melanocytes in mouse (Grimm et al., 2007; Kim et al., } \\
\text { 2007; Xu et al., 2007; Nagata et al., 2008) }\end{array}$ & Cuajungco and Samie, 2008 \\
\hline TRPM5 & TRPM5 signal transduction pathways are relevant to drugs that modulate taste & Liman, 2007 \\
\hline
\end{tabular}

garlic extracts, acrolein, an $\alpha, \beta$-unstaurated aldehyde that acts as an irritant in tear gas, vehicle exhaust and burning vegetation, and volatile general anesthetics, such as isofluorane. In addition, TRPA1 is a target of endogenous inflammatory agents, including products of lipid peroxidation and the proalgesic agent bradykinin (Bandell et al., 2004; Jordt et al., 2004; Bautista et al., 2006; Trevisani et al., 2007; Andersson et al., 2008). TRPA1-deficient neurons show little to no response to these compounds, and TRPA1-deficient animals display attenuated pain behaviors or hypersensitivity after exposure to these irritants (Bautista et al., 2006; Kwan et al., 2006; Matta et al., 2008). These findings demonstrate that TRPA1 is the main molecular site through which a variety of environmental irritants and endogenous inflammatory mediators activate the pain pathway.

Both TRPA1 and TRPM8 had been proposed previously to mediate cold nociception (McKemy et al., 2002; Peier et al., 2002; Story et al., 2003). To elucidate the role of these channels in cold sensation, cellular and behavioral cold responses were measured in mice lacking TRPA1 or TRPM8. Cultured sensory neurons and intact sensory nerve fibers from TRPM8-deficient mice were found to exhibit profoundly diminished responses to cold. Consistent with this finding, these animals themselves showed clear behavioral deficits with respect to their ability to discriminate between cold and warm surfaces. TRPA1-deficient mice, however, displayed no such deficits (Bautista et al., 2007; Colburn et al., 2007; Dhaka et al., 2007). These findings demonstrate an essential and predominant role for TRPM8 in thermosensation, over a wide range of cold temperatures.

\section{TRPM7 contributes to ischemic cell death of neurons}

Death of neurons occurs in neurodegenerative diseases and in stroke, and there is evidence that normally functioning TRP family members promote cell death in certain circumstances. Ischemic cell death is thought to involve a $\mathrm{Ca}^{2+}$ signaling, the generation of intracellular free radicals, and mitochondrial dysfunction. The clinical failure and nonspecific effects of calcium channel blockers and free radical scavengers highlight the importance of determining the molecular events that cause ischemic death; only in this way will valid therapeutic targets be identified. Several channels of the TRPM family have been implicated in ischemic cell death and represent novel targets for therapeutic research. Indeed, TRPM7 knockdown both in vitro and in vivo can prevent neuronal death in experimental models of stroke (Aarts et al., 2003) (M. Aarts, unpublished observations). Dr. Michelle Aarts (University of Toronto, Scarborough, Toronto, Canada) has been studying the mechanism by which TRPM7 facilitates cell death in these models. Cation channels are believed to regulate acute neuronal death, via both the regulation of intra- cellular $\mathrm{Ca}^{2+}$ and intracellular signaling. However, what interactions exist between TRPM channel proteins and what part each protein plays in ischemic disease remain unknown. In this context, it is intriguing that the processes in anoxic injury as resolved by TRPM7 knockdown are attributed to the TRPM2 channel in vitro. Recombinant TRPM2 is activated by the direct application of both hydrogen peroxide and ADP ribose, the latter being a cleavage product released from mitochondria during oxidative stress (Kraft et al., 2004; Miller, 2004; Kolisek et al., 2005). Recently, TRPM2 was shown to be upregulated in brain ischemia, and its activation has been linked to the activity of polyADP ribose polymerase, a nuclear enzyme that is activated in ischemic injury (Fonfria et al., 2006). These findings suggest that TRPM7 and TRPM2 functionally interact during anoxia-induced cell death in vitro.

TRPM channels within the cerebrovascular network may also mediate constrictive forces that exacerbate tissue death after ischemic injury. This possibility is supported by new evidence that TRPM members act as mechano-stimulated channels. Vascular (smooth muscle) damage has been shown to lead to dramatic enhancement of TRPM7 channel expression at the cell surface (Numata et al., 2007b), and TRPM7 can be activated by cellular swelling (Numata et al., 2007a). This vascular role may be linked to the interaction of TRPM7 with cytoskeletal elements and to its proposed role in regulating cell morphology (Dorovkov and Ryazanov, 2004; Clark et al., 2006). TRPM4 activation by $\left[\mathrm{Ca}^{2+}\right]_{\mathrm{i}}$ has also been shown to induce contraction in cerebral vessels (Reading and Brayden, 2007). Together, these finding suggest that TRPM channels may exacerbate ischemic conditions by decreasing critical blood flow to the brain. The identification of new protein interactions will lead to discovery of the pathways that are downstream of TRPM proteins and govern cell survival.

\section{Mutations in the TRPML1 gene cause a lysosomal storage disease}

The functions of TRP channels in normal physiology are widespread, and so an association between a variety of disease and mutant TRP channel genes might be expected. One example is a lysosomal storage disease, which include genetic conditions that impair the function or localization of proteins that are responsible for the digestion or absorption of endocytosed materials. The resulting cellular "indigestion" causes a buildup of intracellular storage inclusions that contain unprocessed lipids, proteins, or macromolecular complexes. Most lysosomal storage diseases are associated with degenerative processes and cause severe developmental delays, cognitive disabilities, blindness, and early death. An example of such a disease is mucolipidosis type IV (MLIV) (Slaugenhaupt, 2002; Bach, 2005), which is caused by mutations 
in a gene termed MCOLN1 (Bargal et al., 2000; Bassi et al., 2000; Sun et al., 2000). This gene encodes the ion channel TRPML1, which is localized in lysosomes. The debate over TRPML1 function focuses primarily on whether this channel (1) directly modulates membrane traffic within the lower portion of the endocytic pathway (Piper and Luzio, 2004) or (2) regulates lysosomal ion homeostasis (Miedel et al., 2008) (this controversy reviewed by Zeevi et al., 2007). Identifying the role of TRPML1 in the endocytic pathway will be absolutely crucial, because it will define the direction of the future search for pharmacological interventions for MLIV.

Membrane traffic delays have been demonstrated in human skin fibroblasts affected by MLIV; this led to conclusion that TRPML1 directly regulates membrane traffic (LaPlante et al., 2004; Treusch et al., 2004; Bach, 2005; Pryor et al., 2006). This is the first indication that ion channels may be involved in intracellular membrane fusion/fission events. However, a serous limitation of this experimental system is that the chronic accumulation of undigested lipids in these cells may affect the ability of traffic markers to enter organelles, misleadingly manifesting as traffic delays. In order to circumvent this problem, the group of Dr. Kirill Kiselyov (University of Pittsburgh, Pittsburgh, PA) developed a small interfering RNA-driven, TRPML1 acute knockdown system and tested the immediate effects of TRPML1 knockdown on membrane traffic (Miedel et al., 2008). No membrane traffic delays were detected in acutely TRPML1-deficient cells, which argues that the basis of this disease is metabolic rather than a defect in trafficking. This finding suggests that enzyme replacement therapies for the treatment of MLIV should focus on the formulation of modified enzymes to work in the MLIVspecific ionic environment and emphasizes the need for a deeper inquiry into TRPML1 permeability and regulation.

Like most lysosomal storage diseases, MLIV is a neurodegenerative disorder. Although degenerative processes have been shown in all lysosomal storage diseases, a correlation between the number of storage inclusions and the severity of the degenerative processes is not always apparent. This suggests that a specific mechanism set in motion by lysosomal deficiencies drives degenerative processes in these diseases. Dr. Kiselyov's group found that the suppression of lysosome function in lysosomal storage diseases inhibits the utilization of aged mitochondria (Jennings et al., 2006). The resulting buildup of effete mitochondria promotes the proapoptotic effects of $\mathrm{Ca}^{2+}$ and results in a higher percentage of cell death when the cells are stimulated by hormones and neurotransmitters (Kim et al., 2007; Kiselyov and Muallem, 2008). Similar results have been reported recently in other experimental systems (Pacheco et al., 2007; Settembre et al., 2008; Vergarajauregui et al., 2008). These results explain the specificity of neurodegeneration in lysosomal storage diseases and suggest that caspase inhibitors may be used as complimentary treatments for lysosomal storage diseases.

\section{Deafness in varitint-waddler mutant mice results from constitutive activation of TRPML3}

Although no disease has yet been associated with TRPML3, the phenotype of mouse Trpml3 mutants suggest that this gene should be considered a candidate locus in congenital diseases that include sensorineural hearing loss. Thus, varitint-waddler $(\mathrm{Va})$ mutant mice, which are deaf and have vestibular impairment, bear a semidominant mutation in the TRP channel-encoding gene Trpml3 (Cloudman and Bunker, 1945; Deol, 1954; Cable and Steel, 1998; Di Palma et al., 2002). Varitint-waddler mice display several inner ear defects, including (1) reduction or elim- ination of the endocochlear potential, (2) anatomical alteration of the stria vascularis, the cochlear structure that generates this potential, with its marginal cells rounding up and losing their cytoplasmic processes, and (3) degeneration and loss of sensory hair cells, which display apical deformations at embryonic stages and are later extruded from the sensorineural epithelium (Deol, 1954; Cable and Steel, 1998). The $V a$ mutation results in an alanine-to-proline substitution at residue 419 (A419P) of TRPML3, and this is thought to break the $\alpha$ helix of the fifth transmembrane domain (S5), near the pore (Di Palma et al., 2002; Grimm et al., 2007). How this form of TRPML3 contributes to cell death is unknown. Jaime García-Añoveros (Northwestern University, Evanston, IL) and his coworkers have been studying this issue.

Is the effect of TRPML3 on cell viability cell autonomous? The García-Añoveros group demonstrated that many epithelial cells that line the cochlear scala media and the vestibular endolymphatic compartments of the inner ear express TRPML3 mRNA (Nagata et al., 2008). These include the marginal cells of the stria vascularis and the equivalent dark cells of the vestibule, as well as the cochlear and vestibular mechanosensory hair cells, which degenerate in varitint-waddler mice. Furthermore, this group showed that, when heterologously expressed in LLC-PK1-CL4 epithelial cells, which serve as a culture model for hair cells, a TRPML3::GFP (green fluorescent protein) fusion protein accumulated in lysosomal vacuoles as well as in espin-enlarged microvilli that resemble stereocilia (Nagata et al., 2008). When these cells express the mutant TRPML3 (A419P), they die and are extruded from the epithelium in a manner reminiscent of the degeneration of hair cells in $V a$ mice (Nagata et al., 2008). Together, these findings suggest that hair cell death in varitint-waddler mice occurs because of cell-autonomous expression of mutant TRPML3.

What effect does the A419P mutation have on TRPML3 function? Like many other TRP channels, TRPML3 forms cation channels that normally open only in response to high positive potentials and display outer rectification. However, these channels can also open at negative potentials generating double rectification (Kim et al., 2007; Nagata et al., 2008). TRPML3 channels have a preference for calcium over sodium and potassium and are blocked by gadolinium and verapamil but not by ruthenium red, gentamycin, or amiloride (Xu et al., 2007; Nagata et al., 2008). They have permeabilities ranging from $50 \mathrm{pS}$ (at negative potentials) to $70 \mathrm{pS}$ (at positive potentials) (Nagata et al., 2008). The A419P mutation does not affect either the conductance or permeability of the TRPML3 channel. Instead, this gain-of-function mutation greatly enhances the open probability of the channel at hyperpolarized potentials (Nagata et al., 2008). The result of this hyperactivity is a large inwardly rectifying cationic current and severe cellular depolarization (Grimm et al., 2007; Kim et al., 2007; Xu et al., 2007; Nagata et al., 2007, 2008). Of note, recent work from the Clapham laboratory indicates that the pale coat color of varitint-waddler mutants likely results from the death of melanocytes (Xu et al., 2007). In summary, these findings suggest that constitutive activity of TRPML3 (A419P) channels at physiological potentials likely underlies the melanocyte cell loss, hair cell degeneration, and deafness that characterize varitint-waddler mice.

\section{TRPM7 prevents melanin-synthesis-dependent death of embryonic melanocytes}

TRPM7 seems a prime candidate to be a disease locus because it is required for viability of several cell types. Specifically, TRPM7 
knockdown in B-cells, retinoblastoma, and smooth-muscle cell lines causes growth arrest and/or cell death (Nadler et al., 2001; Hanano et al., 2004; He et al., 2005). Supporting an essential role for TRPM7 in normal development, trpm 7 mutants have been isolated several times in phenotype-based mutagenesis screens in zebrafish. Two of these alleles have been molecularly characterized; both carry mutations that cause a frame shift in sequence encoding the intracellular C terminus (Elizondo et al., 2005). The phenotype of embryos homozygous for either of these alleles resembles that in embryos injected with $\operatorname{trp} m 7$ antisense oligonucleotides, implying that the alleles are hypomorphs (loss-offunction) (Elizondo et al., 2005). Zebrafish embryos homozygous for mutant alleles of $\operatorname{trp} m 7$ display a range of phenotypes at various developmental stages. At embryonic stages, $\operatorname{trpm} 7$ mutants are characterized by the death of embryonic melanocytes and a transient period of paralysis (Kelsh et al., 1996; Arduini and Henion, 2004; Cornell et al., 2004); at larval stages and adult stages, they display dwarfism, abnormal skeletogenesis, and kidney stones (Elizondo et al., 2005). Of note, knockdown of TRPM7 expression caused concomitant reduction of TRPM2 expression in cultured cortical neurons (Aarts et al., 2003); it is an interesting and testable possibility that reduction of trpm2 expression occurs in zebrafish $\operatorname{trpm} 7$ mutants and contributes to phenotypes therein.

Robert Cornell's group (University of Iowa, Iowa City, IA) has been investigating the mode of melanocyte cell death and the cellular underpinnings of paralysis in zebrafish $\operatorname{trpm} 7$ mutant embryos. Application of a broad-specificity caspase inhibitor, which prevents melanocyte cell death in zebrafish embryos mutant for the gene encoding the receptor tyrosine kinase Kit, does not have this effect in $\operatorname{trpm} 7$ mutants, implying that melanocyte death in these mutants does not occur by apoptosis (McNeill et al., 2007). In contrast, supplementing embryo medium with magnesium, but not calcium, rescued melanocyte cell death in $\operatorname{trpm} 7$, but not kit, mutants. Interestingly, the inhibition of melanin synthesis via application of a tyrosinase inhibitor also served to prevent melanocyte cell death in $\operatorname{trpm} 7$ mutants (McNeill et al., 2007). Combined with the fact that the intermediates of melanin synthesis are toxic reactive oxygen species, these findings imply that loss of Trpm7 leads to magnesium deficiency in melanophores, resulting in a buildup of toxic intermediates of melanin synthesis that induce necrotic cell death. Notably, the loss of TRPM7 and excess TRPML3 activity both result in the death of melanocytes (McNeill et al., 2007; Xu et al., 2007), possibly revealing a complex interaction between these channels.

Paralysis in zebrafish trpm 7 mutant embryos is intriguing because of the association of TRPM7 with a neurodegenerative disease in humans, but its cellular basis remains unknown. Thus, a hypomorphic variant of TRPM7, encoding a channel with reduced propensity to close in response to intracellular magnesium, is associated with increased risk for the neurodegenerative disease lytico bodig, a disease with neurofibrillary tangles and features of amyotrophic lateral sclerosis and parkinsonism (Hermosura et al., 2005) [TRPM2 may also be associated with this disease (for review, see Hermosura and Garruto, 2007)]. Dopaminergic neurons share similar metabolic chemistry with melanocytes, and the byproducts of dopamine metabolism are also known to be toxic. Therefore, it is possible that, like melanocytes, dopaminergic neurons require TRPM7 to prevent toxic buildup of dopamine metabolites. An alternative explanation for paralysis in TRPM7 mutants is abnormal cholinergic signaling at the neuromuscular junction or perhaps in the brain because cholinergic neurons in the sympathetic neurons require TRPM7 for normal synaptic transmission (Krapivinsky et al., 2006; Brauchi et al., 2008). Additional exploration of the cellular basis of paralysis in zebrafish trpm7 mutants may yield insight into the etiology of lytico bodig and potentially other neurodegenerative diseases.

\section{Some TRP channels are regulated by G-protein-coupled receptors}

The accumulating evidence that TRP channels contribute to disease processes motivates an improved understanding of how TRP channels are regulated. The prototypical TRP channel, dTRP, mediates phototransduction in Drosophila, and similarly many vertebrate TRP channels are involved in sensory transduction. At least six TRP channels are directly gated by sensory stimuli, whereas others, such as dTRP, are activated downstream of G-protein-coupled receptors (GPCRs). This latter class includes TRPC2, an ion channel expressed in the pheromone-sensing vomeronasal organ of mammals (Liman et al., 1999; Stowers et al., 2002), TRPM5, an ion channel that is primarily restricted to chemosensory cells (Perez et al., 2002; Zhang et al., 2003), and TRPA1 and TRPV1, two ion channels that are involved in nociception (Jordt et al., 2003; Dhaka et al., 2006). In nonsensory tissues, including muscle and brain, some TRP channels may, likewise, transduce the binding of neurotransmitters to GPCRs into electrical responses (Clapham, 2003).

The general model for understanding the GPCR-based mechanism of TRP channel activation is based on extensive work in the fly photoreceptor (Montell, 1999; Hardie, 2007). A key component of this system is PLC (NorpA), which is activated after absorption of light by rhodopsin, and is essential for phototransduction (Bloomquist et al., 1988). PLC activation leads to the hydrolysis of phosphatidyl inositol $(4,5)$ bisphospate [PI(4,5)P2] into diacylglycerol (DAG) and inositol trisphosphate $\left(\mathrm{IP}_{3}\right)$, as well as to the release of intracellular $\mathrm{Ca}^{2+}$ (Berridge, 1993); any of these products might be the one that activates the Drosophila TRP channels. Several lines of evidence suggest that it is the lipid metabolites of DAG that activate the fly TRP channels and mediate phototransduction (Chyb et al., 1999; Leung et al., 2008). Unfortunately, the failure of these compounds to activate native channels has impeded progress in confirming this possibility (Hardie, 2007).

Taste is an excellent system in which to study the regulation of TRP channels that lie downstream of GPCR signaling because many of the molecular components of taste transduction have been identified, and the sensory stimuli are well characterized. Bitter is detected by a small family of GPCRs, whereas sweet and umami are each detected by a heterodimeric GPCR (Chandrashekar et al., 2006). Receptors for bitter, sweet, and umami tastes are coupled through trimeric G-proteins to the enzyme PLC $\beta 2$, whose activity is essential for taste transduction (Zhang et al., 2003). Also essential is the ion channel TRPM5 (Perez et al., 2002; Zhang et al., 2003; Damak et al., 2006), as revealed by the near insensitivity of TRPM5 knock-out mice to both bitter and sweet substances (Zhang et al., 2003; Damak et al., 2006).

How, then, does PLC activation lead to a change in the gating of TRPM5 channels? In the laboratory of Emily Liman (University of Southern California, Los Angeles, CA), this question has been addressed by studying the responses of TRPM5 channels, in both cells expressing heterologous TRPM5 and taste cells expressing native TRPM5, to putative second messengers. Initial studies by this group and others have shown that, when expressed heterologously, TRPM5 forms a nonselective cation channel that is activated by the elevation of intracellular $\mathrm{Ca}^{2+}$ (Hofmann et al., 2003; Liu and Liman, 2003; Prawitt et al., 2003) or by the 
depletion of $\mathrm{Ca}^{2+}$ stores (Perez et al., 2002). More recently, the Liman group showed that intracellular $\mathrm{Ca}^{2+}$ released from $\mathrm{IP}_{3}$ stores gates TRPM5 in native taste receptor cells (Zhang et al., 2007) and that, after sustained activation, TRPM5 channels, in both native and heterologous cells, desensitize by a process that may be mediated be the depletion of PI $(4,5) \mathrm{P} 2$ (Liu and Liman, 2003). Together, these data suggest a model for taste transduction whereby elevation of $\mathrm{IP}_{3}$ and the ensuing release of intracellular $\mathrm{Ca}^{2+}$ gates TRPM5, leading to membrane depolarization. Although this mechanism cannot explain phototransduction in Drosophila, in which $\mathrm{Ca}^{2+}$ has no direct activating effect (Ranganathan et al., 1994; Hardie, 1995) and the $\mathrm{IP}_{3}$ receptor is dispensable (Acharya et al., 1997; Raghu et al., 2000), it may be applicable to other systems in which $\mathrm{Ca}^{2+}$-activated TRP channels participate.

\section{References}

Aarts MM, Tymianski M (2005) TRPM7 and ischemic CNS injury. Neuroscientist 11:116-123.

Aarts M, Iihara K, Wei WL, Xiong ZG, Arundine M, Cerwinski W, MacDonald JF, Tymianski M (2003) A key role for TRPM7 channels in anoxic neuronal death. Cell 115:863-877.

Acharya JK, Jalink K, Hardy RW, Hartenstein V, Zuker CS (1997) InsP3 receptor is essential for growth and differentiation but not for vision in Drosophila. Neuron 18:881-887.

Ambudkar IS (2007) Trafficking of TRP channels: determinants of channel function. Handb Exp Pharmacol 541-557.

Andersson DA, Gentry C, Moss S, Bevan S (2008) Transient receptor potential A1 is a sensory receptor for multiple products of oxidative stress. J Neurosci 28:2485-2494.

Arduini BL, Henion PD (2004) Melanophore sublineage-specific requirement for zebrafish touchtone during neural crest development. Mech Dev 121:1353-1364.

Bach G (2005) Mucolipin 1: endocytosis and cation channel: a review. Pflugers Arch 451:313-317.

Bandell M, Story GM, Hwang SW, Viswanath V, Eid SR, Petrus MJ, Earley TJ, Patapoutian A (2004) Noxious cold ion channel TRPA1 is activated by pungent compounds and bradykinin. Neuron 41:849-857.

Bargal R, Avidan N, Ben-Asher E, Olender Z, Zeigler M, Frumkin A, RaasRothschild A, Glusman G, Lancet D, Bach G (2000) Identification of the gene causing mucolipidosis type IV. Nat Genet 26:118-123.

Bassi MT, Manzoni M, Monti E, Pizzo MT, Ballabio A, Borsani G (2000) Cloning of the gene encoding a novel integral membrane protein, mucolipidin-and identification of the two major founder mutations causing mucolipidosis type IV. Am J Hum Genet 67:1110-1120.

Bautista DM, Jordt SE, Nikai T, Tsuruda PR, Read AJ, Poblete J, Yamoah EN, Basbaum AI, Julius D (2006) TRPA1 mediates the inflammatory actions of environmental irritants and proalgesic agents. Cell 124:1269-1282.

Bautista DM, Siemens J, Glazer JM, Tsuruda PR, Basbaum AI, Stucky CL, Jordt SE, Julius D (2007) The menthol receptor TRPM8 is the principal detector of environmental cold. Nature 448:204-208.

Berridge MJ (1993) Inositol trisphosphate and calcium signalling. Nature 361:315-325.

Bloomquist BT, Shortridge RD, Schneuwly S, Perdew M, Montell C, Steller H, Rubin G, Pak WL (1988) Isolation of a putative phospholipase C gene of Drosophila, norpA, and its role in phototransduction. Cell 54:723-733.

Brauchi S, Krapivinsky G, Krapivinsky L, Clapham DE (2008) TRPM7 facilitates cholinergic vesicle fusion with the plasma membrane. Proc Natl Acad Sci U S A 105:8304-8308.

Cable J, Steel KP (1998) Combined cochleo-saccular and neuroepithelial abnormalities in the Varitint-waddler-J (VaJ) mouse. Hear Res 123:125-136.

Caterina MJ, Schumacher MA, Tominaga M, Rosen TA, Levine JD, Julius D (1997) The capsaicin receptor: a heat-activated ion channel in the pain pathway. Nature 389:816-824.

Caterina MJ, Leffler A, Malmberg AB, Martin WJ, Trafton J, Petersen-Zeitz KR, Koltzenburg M, Basbaum AI, Julius D (2000) Impaired nociception and pain sensation in mice lacking the capsaicin receptor. Science 288:306-313.
Chandrashekar J, Hoon MA, Ryba NJ, Zuker CS (2006) The receptors and cells for mammalian taste. Nature 444:288-294.

Chyb S, Raghu P, Hardie RC (1999) Polyunsaturated fatty acids activate the Drosophila light-sensitive channels TRP and TRPL. Nature 397:255-259.

Clapham DE (2003) TRP channels as cellular sensors. Nature 426:517-524.

Clark K, Langeslag M, van Leeuwen B, Ran L, Ryazanov AG, Figdor CG, Moolenaar WH, Jalink K, van Leeuwen FN (2006) TRPM7, a novel regulator of actomyosin contractility and cell adhesion. EMBO J 25:290-301.

Cloudman A, Bunker L (1945) The varitint-waddler mouse. A dominant mutation in Mus Musculus. J Hered 36:259-263.

Colburn RW, Lubin ML, Stone DJ Jr, Wang Y, Lawrence D, D'Andrea MR, Brandt MR, Liu Y, Flores CM, Qin N (2007) Attenuated cold sensitivity in TRPM8 null mice. Neuron 54:379-386.

Cornell RA, Yemm E, Bonde G, Li W, d'Alençon C, Wegman L, Eisen J, Zahs A (2004) Touchtone promotes survival of embryonic melanophores in zebrafish. Mech Dev 121:1365-1376.

Cuajungco MP, Samie MA (2008) The varitint-waddler mouse phenotypes and the TRPML3 ion channel mutation: cause and consequence. Pflugers Arch. Advance online publication. Retrieved Sept 15, 2008. doi: 10.1007/s00424-008-0523-4.

Damak S, Rong M, Yasumatsu K, Kokrashvili Z, Perez CA, Shigemura N, Yoshida R, Mosinger B Jr, Glendinning JI, Ninomiya Y, Margolskee RF (2006) Trpm5 null mice respond to bitter, sweet, and umami compounds. Chem Senses 31:253-264.

Deol M (1954) The anomalies of the labyrinth of the mutants varitintwaddler, shaker-2 and jerker in the mouse. J Genet 52:562-588.

Dhaka A, Viswanath V, Patapoutian A (2006) Trp ion channels and temperature sensation. Annu Rev Neurosci 29:135-161.

Dhaka A, Murray AN, Mathur J, Earley TJ, Petrus MJ, Patapoutian A (2007) TRPM8 is required for cold sensation in mice. Neuron 54:371-378.

Di Palma F, Belyantseva IA, Kim HJ, Vogt TF, Kachar B, Noben-Trauth K (2002) Mutations in Mcoln3 associated with deafness and pigmentation defects in varitint-waddler (Va) mice. Proc Natl Acad Sci U S A 99:14994-14999.

Dorovkov MV, Ryazanov AG (2004) Phosphorylation of annexin I by TRPM7 channel-kinase. J Biol Chem 279:50643-50646.

Elizondo MR, Arduini BL, Paulsen J, MacDonald EL, Sabel JL, Henion PD, Cornell RA, Parichy DM (2005) Defective skeletogenesis with kidney stone formation in dwarf zebrafish mutant for trpm7. Curr Biol 15:667-671.

Flockerzi V (2007) An introduction on TRP channels. Handb Exp Pharmacol 1-19.

Fonfria E, Mattei C, Hill K, Brown JT, Randall A, Benham CD, Skaper SD, Campbell CA, Crook B, Murdock PR, Wilson JM, Maurio FP, Owen DE, Tilling PL, McNulty S (2006) TRPM2 is elevated in the tMCAO stroke model, transcriptionally regulated, and functionally expressed in $\mathrm{C} 13 \mathrm{mi}-$ croglia. J Recept Signal Transduct Res 26:179-198.

Gaudet R (2008) TRP channels entering the structural era. J Physiol 586:3565-3575.

Grimm C, Cuajungco MP, van Aken AF, Schnee M, Jörs S, Kros CJ, Ricci AJ, Heller S (2007) A helix-breaking mutation in TRPML3 leads to constitutive activity underlying deafness in the varitint-waddler mouse. Proc Natl Acad Sci U S A 104:19583-19588.

Hanano T, Hara Y, Shi J, Morita H, Umebayashi C, Mori E, Sumimoto H, Ito $\mathrm{Y}$, Mori Y, Inoue R (2004) Involvement of TRPM7 in cell growth as a spontaneously activated $\mathrm{Ca}^{2+}$ entry pathway in human retinoblastoma cells. J Pharmacol Sci 95:403-419.

Hardie RC (1995) Photolysis of caged $\mathrm{Ca}^{2+}$ facilitates and inactivates but does not directly excite light-sensitive channels in Drosophila photoreceptors. J Neurosci 15:889-902.

Hardie RC (2007) TRP channels and lipids: from Drosophila to mammalian physiology. J Physiol 578:9-24.

He Y, Yao G, Savoia C, Touyz RM (2005) Transient receptor potential melastatin 7 ion channels regulate magnesium homeostasis in vascular smooth muscle cells: role of angiotensin II. Circ Res 96:207-215.

Hermosura MC, Garruto RM (2007) TRPM7 and TRPM2-Candidate susceptibility genes for Western Pacific ALS and PD? Biochim Biophys Acta 1772:822-835.

Hermosura MC, Nayakanti H, Dorovkov MV, Calderon FR, Ryazanov AG, Haymer DS, Garruto RM (2005) A TRPM7 variant shows altered sensitivity to magnesium that may contribute to the pathogenesis of two Gua- 
manian neurodegenerative disorders. Proc Natl Acad Sci USA 102:11510-11515.

Hofmann T, Chubanov V, Gudermann T, Montell C (2003) TRPM5 is a voltage-modulated and $\mathrm{Ca}^{2+}$-activated monovalent selective cation channel. Curr Biol 13:1153-1158.

Iuga AO, Lerner EA (2007) TRP-ing up melanophores: TRPM7, melanin synthesis, and pigment cell survival. J Invest Dermatol 127:1855-1856.

Jennings JJ Jr, Zhu JH, Rbaibi Y, Luo X, Chu CT, Kiselyov K (2006) Mitochondrial aberrations in mucolipidosis Type IV. J Biol Chem 281:39041-39050.

Jordt SE, McKemy DD, Julius D (2003) Lessons from peppers and peppermint: the molecular logic of thermosensation. Curr Opin Neurobiol 13:487-492.

Jordt SE, Bautista DM, Chuang HH, McKemy DD, Zygmunt PM, Högestätt ED, Meng ID, Julius D (2004) Mustard oils and cannabinoids excite sensory nerve fibres through the TRP channel ANKTM1. Nature 427:260-265.

Kelsh RN, Brand M, Jiang YJ, Heisenberg CP, Lin S, Haffter P, Odenthal J, Mullins MC, van Eeden FJ, Furutani-Seiki M, Granato M, Hammerschmidt M, Kane DA, Warga RM, Beuchle D, Vogelsang L, NüssleinVolhard C (1996) Zebrafish pigmentation mutations and the processes of neural crest development. Development 123:369-389.

Kim HJ, Li Q, Tjon-Kon-Sang S, So I, Kiselyov K, Muallem S (2007) Gainof-function mutation in TRPML3 causes the mouse Varitint-Waddler phenotype. J Biol Chem 282:36138-36142.

Kiselyov K, Muallem S (2008) Mitochondrial $\mathrm{Ca}^{2+}$ homeostasis in lysosomal storage diseases. Cell Calcium 44:103-111.

Kolisek M, Beck A, Fleig A, Penner R (2005) Cyclic ADP-ribose and hydrogen peroxide synergize with ADP-ribose in the activation of TRPM2 channels. Mol Cell 18:61-69.

Kraft R, Grimm C, Grosse K, Hoffmann A, Sauerbruch S, Kettenmann H, Schultz G, Harteneck C (2004) Hydrogen peroxide and ADP-ribose induce TRPM2-mediated calcium influx and cation currents in microglia. Am J Physiol Cell Physiol 286:C129-C137.

Krapivinsky G, Mochida S, Krapivinsky L, Cibulsky SM, Clapham DE (2006) The TRPM7 ion channel functions in cholinergic synaptic vesicles and affects transmitter release. Neuron 52:485-496.

Kwan KY, Allchorne AJ, Vollrath MA, Christensen AP, Zhang DS, Woolf CJ, Corey DP (2006) TRPAl contributes to cold, mechanical, and chemical nociception but is not essential for hair-cell transduction. Neuron 50:277-289.

LaPlante JM, Ye CP, Quinn SJ, Goldin E, Brown EM, Slaugenhaupt SA, Vassilev PM (2004) Functional links between mucolipin-1 and $\mathrm{Ca}^{2+}$ dependent membrane trafficking in mucolipidosis IV. Biochem Biophys Res Commun 322:1384-1391.

Leung HT, Tseng-Crank J, Kim E, Mahapatra C, Shino S, Zhou Y, An L, Doerge RW, Pak WL (2008) DAG lipase activity is necessary for TRP channel regulation in Drosophila photoreceptors. Neuron 58:884-896.

Liman ER (2007) TRPM5 and taste transduction. Handb Exp Pharmacol 287-298.

Liman ER, Corey DP, Dulac C (1999) TRP2: a candidate transduction channel for mammalian pheromone sensory signaling. Proc Natl Acad Sci U S A 96:5791-5796.

Liu D, Liman ER (2003) Intracellular $\mathrm{Ca}^{2+}$ and the phospholipd PIP2 regulate the taste transduction ion channel TRPM5. Proc Natl Acad Sci U S A 100:15160-15165.

Matta JA, Cornett PM, Miyares RL, Abe K, Sahibzada N, Ahern GP (2008) General anesthetics activate a nociceptive ion channel to enhance pain and inflammation. Proc Natl Acad Sci U S A 105:8784-8789.

McKemy DD, Neuhausser WM, Julius D (2002) Identification of a cold receptor revelas a general role for TRP channels in thermosensation. Nature 416:52-58.

McNeill MS, Paulsen J, Bonde G, Burnight E, Hsu MY, Cornell RA (2007) Cell death of melanophores in zebrafish trpm7 mutant embryos depends on melanin synthesis. J Invest Dermatol 127:2020-2030.

McNulty S, Fonfria E (2005) The role of TRPM channels in cell death. Pflugers Arch 451:235-242.

Miedel MT, Rbaibi Y, Guerriero CJ, Colletti G, Weixel KM, Weisz OA, Kiselyov K (2008) Membrane traffic and turnover in TRP-ML1-deficient cells: a revised model for mucolipidosis type IV pathogenesis. J Exp Med 205:1477-1490.

Miller BA (2004) Inhibition of TRPM2 function by PARP inhibitors pro- tects cells from oxidative stress-induced death. $\mathrm{Br} \mathrm{J}$ Pharmacol 143:515-516.

Montell C (1999) Visual transduction in Drosophila. Annu Rev Cell Dev Biol 15:231-268.

Montell C (2005) TRP channels in Drosophila photoreceptor cells. J Physiol 567:45-51.

Nadler MJ, Hermosura MC, Inabe K, Perraud AL, Zhu Q, Stokes AJ, Kurosaki T, Kinet JP, Penner R, Scharenberg AM, Fleig A (2001) LTRPC7 is a Mg.ATP-regulated divalent cation channel required for cell viability. Nature 411:590-595.

Nagata K, Duggan A, Kumar G, García-Añoveros J (2005) Nociceptor and hair cell transducer properties of TRPA1, a channel for pain and hearing. J Neurosci 25:4052-4061.

Nagata K, Zheng L, Madathany T, Castiglioni AJ, Bartles JR, Garcia-Añoveros J (2007) The varitint-waddler (Va) deafness mutation in TRPML3 generates constitutive, inward rectifying current and casues cellular degeneration. Soc Neurosci Abstr 33:699.12/S12.

Nagata K, Zheng L, Madathany T, Castiglioni AJ, Bartles JR, García-Añoveros J (2008) The varitint-waddler (Va) deafness mutation in TRPML3 generates constitutive, inward rectifying currents and causes cell degeneration. Proc Natl Acad Sci U S A 105:353-358.

Nilius B (2007) TRP channels in disease. Biochim Biophys Acta 1772:805-812.

Numata T, Shimizu T, Okada Y (2007a) TRPM7 is a stretch- and swellingactivated cation channel involved in volume regulation in human epithelial cells. Am J Physiol Cell Physiol 292:C460-C467.

Numata T, Shimizu T, Okada Y (2007b) Direct mechano-stress sensitivity of TRPM7 channel. Cell Physiol Biochem 19:1-8.

Okuhara DY, Hsia AY, Xie M (2007) Transient receptor potential channels as drug targets. Expert Opin Ther Targets 11:391-401.

Pacheco CD, Kunkel R, Lieberman AP (2007) Autophagy in Niemann-Pick $\mathrm{C}$ disease is dependent upon Beclin-1 and responsive to lipid trafficking defects. Hum Mol Genet 16:1495-1503.

Peier AM, Moqrich A, Hergarden AC, Reeve AJ, Andersson DA, Story GM, Earley TJ, Dragoni I, McIntyre P, Bevan S, Patapoutian A (2002) A TRP channel that senses cold stimuli and menthol. Cell 108:705-715.

Pérez CA, Huang L, Rong M, Kozak JA, Preuss AK, Zhang H, Max M, Margolskee RF (2002) A transient receptor potential channel expressed in taste receptor cells. Nat Neurosci 5:1169-1176.

Piper RC, Luzio JP (2004) CUPpling calcium to lysosomal biogenesis. Trends Cell Biol 14:471-473.

Prawitt D, Monteilh-Zoller MK, Brixel L, Spangenberg C, Zabel B, Fleig A, Penner R (2003) TRPM5 is a transient $\mathrm{Ca}^{2+}$-activated cation channel responding to rapid changes in $\left[\mathrm{Ca}^{2+}\right]_{\mathrm{i}}$. Proc Natl Acad Sci U S A 100:15166-15171.

Pryor PR, Reimann F, Gribble FM, Luzio JP (2006) Mucolipin-1 Is a lysosomal membrane protein required for intracellular lactosylceramide traffic. Traffic 7:1388-1398.

Raghu P, Colley NJ, Webel R, James T, Hasan G, Danin M, Selinger Z, Hardie RC (2000) Normal phototransduction in Drosophila photoreceptors lacking an InsP(3) receptor gene. Mol Cell Neurosci 15:429-445.

Ranganathan R, Bacskai BJ, Tsien RY, Zuker CS (1994) Cytosolic calcium transients: spatial localization and role in Drosophila photoreceptor cell function. Neuron 13:837-848.

Reading SA, Brayden JE (2007) Central role of TRPM4 channels in cerebral blood flow regulation. Stroke 38:2322-2328.

Settembre C, Fraldi A, Jahreiss L, Spampanato C, Venturi C, Medina D, de Pablo R, Tacchetti C, Rubinsztein DC, Ballabio A (2008) A block of autophagy in lysosomal storage disorders. Hum Mol Genet 17:119-129.

Slaugenhaupt SA (2002) The molecular basis of mucolipidosis type IV. Curr Mol Med 2:445-450.

Story GM (2006) The emerging role of TRP channels in mechanisms of temperature and pain sensation. Curr Neuropharmacol 4:183-196.

Story GM, Peier AM, Reeve AJ, Eid SR, Mosbacher J, Hricik TR, Earley TJ, Hergarden AC, Andersson DA, Hwang SW, McIntyre P, Jegla T, Bevan S, Patapoutian A (2003) ANKTM1, a TRP-like channel expressed in nociceptive neurons, is activated by cold temperatures. Cell 112:819-829.

Stowers L, Holy TE, Meister M, Dulac C, Koentges G (2002) Loss of sex discrimination and male-male aggression in mice deficient for TRP2. Science 295:1493-1500.

Sun M, Goldin E, Stahl S, Falardeau JL, Kennedy JC, Acierno JS Jr, Bove C, Kaneski CR, Nagle J, Bromley MC, Colman M, Schiffmann R, Slaugen- 
haupt SA (2000) Mucolipidosis type IV is caused by mutations in a gene encoding a novel transient receptor potential channel. Hum Mol Genet 9:2471-2478.

Treusch S, Knuth S, Slaugenhaupt SA, Goldin E, Grant BD, Fares H (2004) Caenorhabditis elegans functional orthologue of human protein h-mucolipin-1 is required for lysosome biogenesis. Proc Natl Acad Sci U S A 101:4483-4488.

Trevisani M, Siemens J, Materazzi S, Bautista DM, Nassini R, Campi B, Imamachi N, Andrè E, Patacchini R, Cottrell GS, Gatti R, Basbaum AI, Bunnett NW, Julius D, Geppetti P (2007) 4-Hydroxynonenal, an endogenous aldehyde, causes pain and neurogenic inflammation through activation of the irritant receptor TRPA1. Proc Natl Acad Sci U S A 104:13519-13524.

Vergarajauregui S, Connelly PS, Daniels MP, Puertollano R (2008) Autoph- agic dysfunction in mucolipidosis type IV patients. Hum Mol Genet 17:2723-2737.

Wang H, Woolf CJ (2005) Pain TRPs. Neuron 46:9-12.

Xu H, Delling M, Li L, Dong X, Clapham DE (2007) Activating mutation in a mucolipin transient receptor potential channel leads to melanocyte loss in varitint-waddler mice. Proc Natl Acad Sci U S A 104:18321-18326.

Zeevi DA, Frumkin A, Bach G (2007) TRPML and lysosomal function. Biochim Biophys Acta 1772:851-858.

Zhang Y, Hoon MA, Chandrashekar J, Mueller KL, Cook B, Wu D, Zuker CS, Ryba NJ (2003) Coding of sweet, bitter, and umami tastes: different receptor cells sharing similar signaling pathways. Cell 112:293-301.

Zhang Z, Zhao Z, Margolskee R, Liman E (2007) The transduction channel TRPM5 is gated by intracellular calcium in taste cells. J Neurosci 27:57775786. 